\title{
Dendrogeomorphological analysis of landslide activity along the planned S-69 road in the Węgierska Górka municipality (Beskid Śląski Mountains, S Poland)
}

\author{
Damian Wiktorowski ${ }^{1}$, Marek Krąpiec ${ }^{1}$, Mateusz Lutka² \\ ${ }^{1}$ AGH University of Science and Technology, Faculty of Geology, Geophysics and Environmental Protection, Department of \\ General Geology and Geotourism; al. A. Mickiewicza 30, 30-059 Krakow, Poland; e-mail: damian.wiktowski 92@gmail.com, \\ mkrapiec@agh.edu.pl \\ ${ }^{2}$ Finance Operation Center, Motorola Solutions, Inc.; ul. Czerwone Maki 82, 30-392 Krakow, Poland; \\ e-mail:mateuszlutka@gmail.com
}

(C) 2017 Authors. This is an open access publication, which can be used, distributed and reproduced in any medium according to the Creative Commons CC-BY 4.0 License requiring that the original work has been properly cited.

Received: 26.06.2017; accepted: 26.08.2017

\begin{abstract}
Our dendrogeomorphological analysis was completed for 4 landslides, situated in the municipality of Węgierska Górka in the Beskid Śląski Mountains in Southern Poland. The local landslides pose a direct threat to the newly designed S-69 expressway running through the north-western part of the municipality. The research material consisted of 127 samples, collected with the use of a Pressler increment borer, from three species of coniferous trees (Norway spruce, Scots pine, and Silver fir). The landslide activity periods were identified on the basis of the splitting of the dendrochronological curves representing the upslope and downslope parts of the tree trunks. The largest number of the studied trees indicated reactions to substrate mass movements in 1964, 1971, 1972, 1984, 1994, 1997, 1998, and 2010. The detailed locations of the sampled trees allowed us to reconstruct the activities of particular landslide sections in time. We identified the fact that parts of the landslides located downslope of the planned road S-69 are more active than parts of the same landslides located above it on the slope. Geological conditions in the studied area favour landslide activity while precipitation is the main triggering factor of landslides.
\end{abstract}

Keywords: landslides, dendrogeomorphology, Beskid Śląski, Polish Flysch Carpathians

\section{INTRODUCTION}

Mass movements are a dangerous geomorphic process that occur almost all over the world (e.g. Butler 1979, Nemčok 1982, Degraff \& Agard 1984, Dikau et al. 1996, Stoffel \& Bollschweiler 2008, Gutierrez et al. 2010). Mass movements in the Flysch Carpathians are also one of the most common geomorphic processes (Starkel 1960, Ziętara 1968, Zabuski et al.1999, Poprawa \& Rączkowski 2000). Landslide areas occurring in the Carpathian Mountains constitute $95 \%$ of all such areas in
Poland (Wójcik \& Wojciechowski 2016). Particular occurrences present essential hazards to infrastructure and (particularly) the roads developed in the Carpathian regions (Poprawa \& Rączkowski 2000). Together with the expansion of tourist infrastructure in the mountains and the construction of new buildings, roads, and hydrotechnical facilities, the hazard posed by land mass movement has increased, especially in the case of repeated landslides. One of the methods allowing the determination of the periodic activity of a given landslide location in the past has been the 
dendrogeomorphological method (Alestalo 1971, Shroder 1978, 1980, Stoffel et al. 2013). The trunks of the trees growing on lands susceptible to landslides are often tilted or bent as a result of land mass movements. Such effects considerably influence the way the trees grow and cause such changes in wood anatomy as eccentric growth (Braam et al. 1987, Krąpiec \& Margielewski 1991, 2000, Wistuba et al. 2012). The more disordered the balance of tree growth by slope movement, the stronger the disproportions which occur in the wood anatomy, associated with the eccentric growth and reactive tree shaping in particular trunk segments (Krąpiec \& Margielewski 1991). By establishing the exact years of the occurrence of such tree growth disturbances, the episodes of landslide movements can be dated with considerable accuracy (Corominas
\& Moya 1999, Stefanini 2004, Wistuba et al. 2013), together with other hydrological (Ballesteros et al. 2011, Stoffel \& Wilford 2012) or geological processes (Jacoby et al. 1988, Baillie 2008), and even those associated with mining (Läänelaidet al. 2009, Läänelaid \& Eckstein 2010, Lageard \& Drew 2008).

In this study, dendrogeomorphological analyses of four landslides were conducted (Tab. 1). The studied landslides are located at Węgierska Górka in the Beskid Śląski Mountains, on the slopes of the side ridge running to the east from Mount Barania Góra: 29115 Nad Zieloną, 29116 Nad Zieloną, 29120 Kubiesówka, 29121 Chupki, 29123 Kubiesówka (landslide numbers refer to the Landslide Protection System (SOPO; access to data: 15 May 2017; database marking - see Kucharska \& Kamiński 2009; Fig. 1).

Table 1

Basic features of studied landslide

\begin{tabular}{|c|c|c|c|}
\hline $\begin{array}{c}\text { Landslide number speci- } \\
\text { fied in the SOPO database }\end{array}$ & Location & $\begin{array}{c}\text { Degree of landslides activity } \\
\text { identified in SOPO database }\end{array}$ & $\begin{array}{c}\text { Surface area } \\
{[\text { ha] }]}\end{array}$ \\
\hline 29115 & Nad Zieloną & N, O, A & 20.26 \\
\hline 29116 & Nad Zieloną & N, O & 3.39 \\
\hline 29120 & Kubiesówka & N, O, A & 12.74 \\
\hline 29121 & Chupki & N, O, A & 7.14 \\
\hline 29123 & Kubiesówka & N, O & 4.1 \\
\hline
\end{tabular}

Explanations: $\mathrm{A}$ - active, $\mathrm{O}$ - periodically active, $\mathrm{N}$ - non-active.

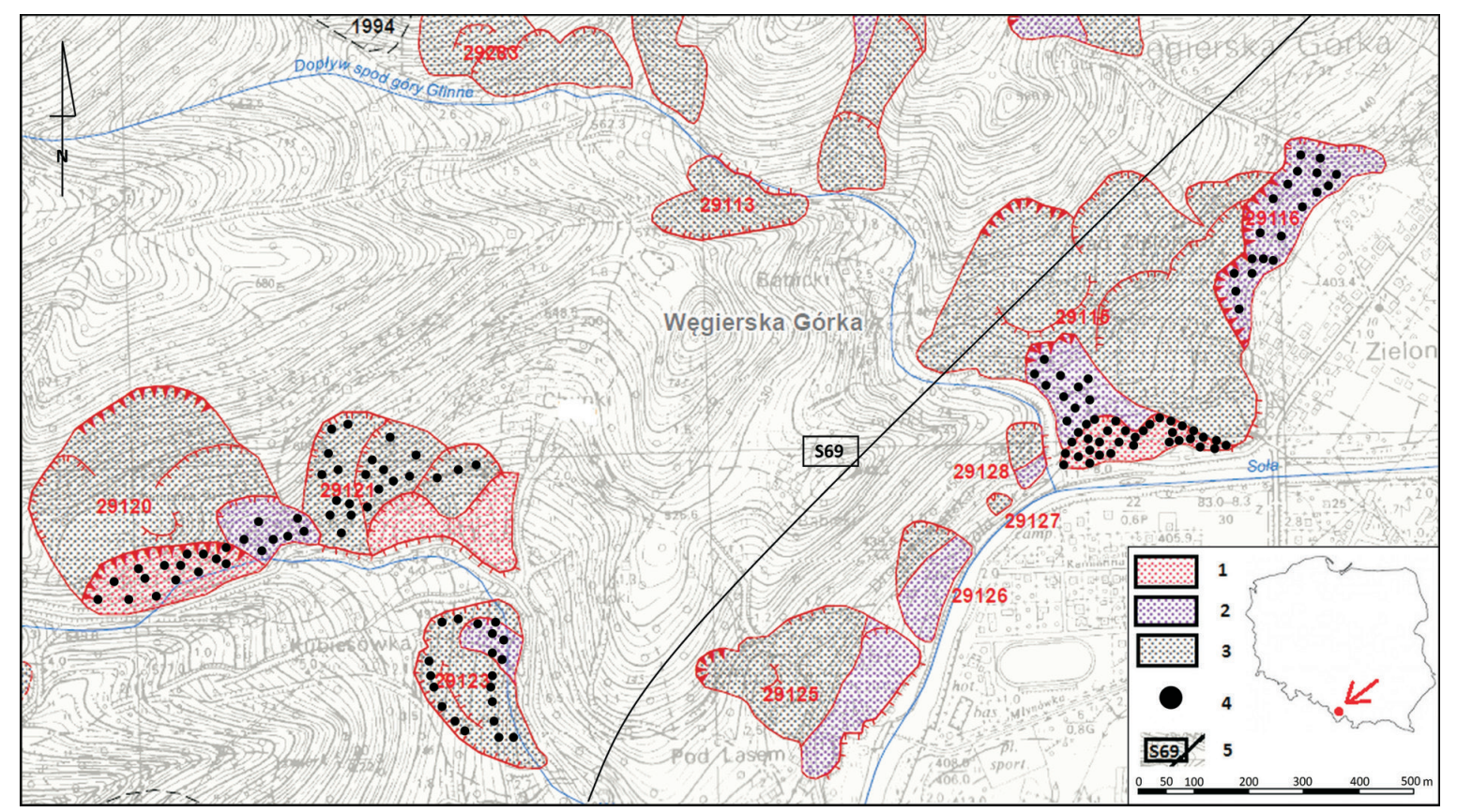

Fig. 1. Location of the study area, with landslide identification marking (based on SOPO Project: Kucharska \& Kamiński 2009): 1 -active landslide, 2 - periodically active landslide, 3 - non-active landslide, 4 -sampled trees, 5 - newly planned S-69 expressway 
The main reason for the dendrochronological study was the fact that the landslides under study posed a threat to the newly designed S-69 expressway running through the north-western part of the Węgierska Górka municipality. The objective of our studies was to determine the activity of studied landslides and frequency of landslide events over the last 80 years along the planned road S- 69 . We also made an attempt to identify the triggering factors of landslide activity in the study area.

\section{STUDY AREA}

The study area is located on the borderlands of the Beskid Śląski Mountains and the Kotlina Żywiecka Basin. The sample comprised an area within the Outer (Flysch) Carpathians, composed mainly of siliciclastic turbidites. Mount Barania Góra is characterised by a complex tectonic structure, with the dominant role played by the tectonic formations caused by folding (Burtan 1973, Bajgier 1989). The study area was situated on the border of the Silesian and Fore-Magura Units, which are composed mainly of the intermittent layers of sandstone and shale, interbedded with variegated shale (Burtan 1973). The contemporary relief of the Beskid Śląski Mountains was formed by the Neogene-Quaternary denudational processes. Fluvial erosion is an essential geomorphological process (Ziętara 1968). Its intensity during floods caused the undercutting of slopes and led to mass movements. The slopes that were inclined in accordance with the bed dipping provided favourable conditions for landslides, as the sandstone material easily slides down the shale layers saturated with water (Zabuski et al. 1999). However, in the case of gentle slopes covered by vegetation, we can observe the slow creep of the slope surface cover, as indicated by tilted tree trunks (Barański 2007). Such landslides, with clearly marked slopes up to several dozen metres in height, are common in the Beskid Śląski Mountains (Bajgier 1989). In the Węgierska Górka municipality area they are particularly frequent; 162 landslides and 18 hazardous areas were identified (Kucharska \& Kamiński 2009). The geological structure of the area and the tectonics of rock masses are associated with numerous dislocations, strongly influencing the spatial distribution of the landslides, as well as their sizes and frequencies of occurrence
(Kucharska \& Kamiński 2009). The landslides identified in one of the sections of the municipality were often situated on developed, forested and bushy lands. There were characteristic landslide relief elements found within large landslides areas: primary and secondary scarps, thresholds and bulging, as well as isolated depressions. Old and inactive landslides showed faint and hardly visible boundaries (Kucharska \& Kamiński 2009).

\section{MATERIAL AND METHODS}

\section{Sampling}

During field work conducted in November 2015, 127 trees were sampled using a Pressler increment borer. 115 trees were sampled with single cores (two opposing radii), whereas 12 trees with 2 cores from up- and downslope sides. Altogether, 139 cores were collected. For collecting samples, we selected trees with trunks which were bent down or up with the direction of sloping (Fig. 2).

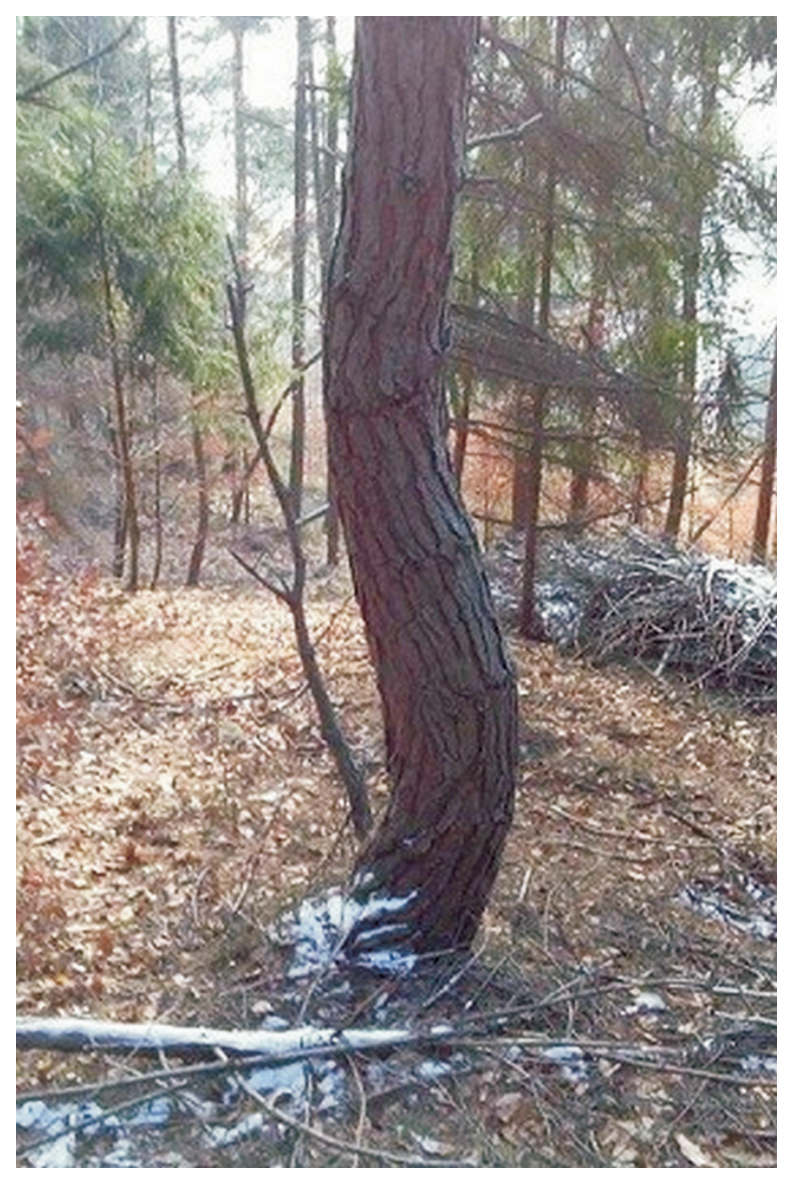

Fig. 2. A tree growing on the landslide area, with a typically bent trunk 
Trees with deformed trunks (bent or tilted) in a way that was characteristic for land surface relocation were identified. Samples were collected from the following three species of coniferous trees: Norway spruce (Picea abies) - 62 trees; Scots pine (Pinus sylvestris L.) - 37 trees; Silver fir (Abies alba) -28 trees. One core from each tree was usually collected by coring the tree.

\section{Processing and measurements}

Sample processing and ring width measurements were conducted with the use of the DENDROLAB equipment, available at the Dendrochronology Laboratory of the AGH University of Science and Technology in Kraków. The equipment set is composed of a measuring device, with the accuracy of $1 / 100 \mathrm{~mm}$, provided with specialist software ' $\mathrm{LDB}$ Pomiary' (according to 'LDB_Pomiary' manual) allowing comprehensive dendrochronological analyses to be conducted. The sequences measured were cross-dated with the reference chronology compiled by Szychowska-Krąpiec (2010) and Malik (personal communication, June 20, 2017) so as to identify false or missing tree rings.

\section{Dendrogeomorphological analysis based on the dendrochronological curve pairs comparison method}

Our analysis was conducted by means of the dendrochronological curve pairs comparison method. We tried to find the characteristic sudden split of a pair of curves of tree rings from opposite sides of the tree, determined by a sudden change of the ring width visible at the opposite sides of the tree trunk which is indicative of landslide movements (Braam 1987, Krąpiec \& Margielewski 1991, Zielski \& Krąpiec 2004).

As a result of the measurements, we obtained the widths of annual rings listed for both upslope and downslope trunk parts of the same tree. Based on those measurements, dendrochronological curves were constructed. Next, LDB software was applied to match the dendrochronological curves originating from the outslope and downslope trunk parts, respectively.

In normal conditions, when trees grow in a stable place (without mass-movements), the tree trunk is straight and tree ring widths are more or less similar on both the upslope and downslope trunk sides. In such cases, once the dendrochronological curves fit each other, they should represent a similar, almost a parallel ring pattern. Trees which were tilted as a result of bedrock gravitational displacements typically have eccentric ring distributions when they return to their vertical position (Alestalo 1971, Krąpiec \& Margielewski 2000). The periods of intense slope activity are visible on the graphs, in the form of sudden ring width increases (equivalent to reaction wood growths), with a concurrent ring reduction (compensation) on the opposite side. The landslide activity period can be identified by the places where the dendrochronological curves are splitting. After some time, however, the curves converge again, caused by the fact that the tree attempts to rebalance itself (Krąpiec \& Margielewski 1991; Fig. 3).
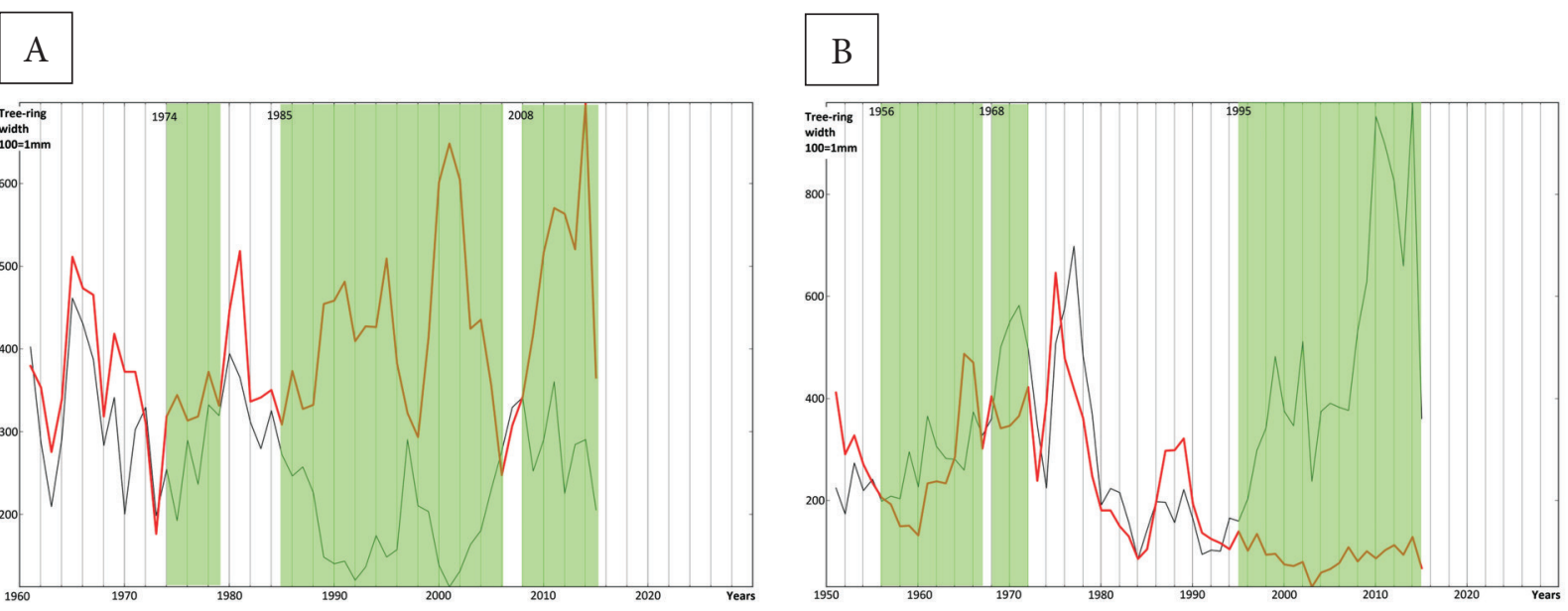

Fig. 3. Dendrograms illustrating the dendrochronological curve split of the studied trees: A) downslope eccentricity; B) outslope eccentricity (black: outslope section; red: downslope section; yellow: periods of dendrochronological curve split) 


\section{RESULTS}

The dendrochronological curves obtained by measuring the annual tree-ring widths were matched in pairs for the upslope and downslope side of the trunk of the same tree. Based on the dendrograms with tree ring curves measured from one tree (downslope and upslope), we dated the start of the dendrochronological curve pair splits that were identical with the beginning of the landslide activity. By summarising the number of events in which we identified an abrupt change in ring width pattern, we received a graph presenting the intensity of landslide events in particular years.

The highest number of trees reacted to landsliding activity in 1997 (17 trees - 13\% trees). In 1964 and 1994, a sudden split of the dendrochronological curves occurred in 16 trees $(12.5 \%$ of the samples). Nearly $10 \%$ of the trees reacted to substrate movement in 1971, 1984, 1998, and 2010. In those particular years, more than 12 trees were found to have reacted to ground instability. Landslide activity also occurred in 1954, 1972, 1990, 1992 , when about $8 \%$ of the studied trees recorded landsliding. We also identified longer periods of landslide activity.

The periods existed mainly in the 1990's, with the peak in 1997 (intense precipitation was recorded in the Carpathians at that time) and in 2000, the year when catastrophic floods and numerous landslides were observed in the Carpathians (Poprawa \& Rączkowski 2000).

However, the results of the dendrogeomorphological analysis conducted separately within the landslide areas situated both above the newly designed S-69 expressway (29120 Kubiesówka, 29121 Chupki, and 29123 Kubiesówka) and below it (29115 Nad Zieloną and $29116 \mathrm{Nad}$ Zieloną) were somewhat different (Fig. 4).

In the case of the $29115 \mathrm{Nad}$ Zieloną and 29116 Nad Zieloną landslides, landsliding occurred mostly in 1994 and 2010, when 10 trees recorded activity (16\% of trees), similarly to the years 1984 and 1998, when 9 trees did so (14\% of the trees). The increased activities of two landslides could also be observed in briefly separated periods in 1954 and 1956 and next in 1964 and 1968, as well as 1971 and 1972. A distinct increase in landslide activity was marked since 1990, the largest activity occurred in the 1990's and the first decade of the $21^{\text {st }}$ century $(1992,1994,1995,1997,1998$, 2000, 2004, 2006, 2008, and 2010).

However, in the landslides of Kubiesówka (29120), Chupki (29121), and Kubiesówka (29123), we could identify the years 1964 and 1997, which were indicated by $50 \%$ more trees than all other analysed years. In 1964 and 1997, 12 trees of the studied individuals recorded landsliding. The dendrochronological curve splits also occurred in 1978, 1984, 1992-1994, 2000, and 2003. In each of those years, a reaction was noted in six trees, i.e. less than $10 \%$ of the population studied. In the years 1954, 1962, 1971, 1972, 1989, 1990, and 2010 the reaction to substrate movement was displayed by only 4 or 5 trees, i.e. $6 \%$ and $8 \%$ trees in the area section, respectively. The greatest landslide activity, similarly to the previous cases, occurred in the 1990's, from 1989 to 2003, with a peak in 1997.

One of the most important issues associated with the present dendrogeomorphological studies of landslides concerned dating not only in time but also in space (Šilhán \& Stoffel 2015). Detailed locations of the sampled trees, by using available maps and GPS receivers, allowed us to develop a spatial analysis of the results obtained. That analysis helped us to track the changes in the rates of substrate relocation in particular landslide sections and draft landslide slope activity maps either for particular years or for several-year long periods. Those maps also helped to follow the changes in the rates of the landsliding process in recent decades (Fig. 5).

The first significant landsliding occurred in 1954-1956, and was associated with the relocations within the active section of the Nad Zielona landslide (29115) and in the eastern section of the Kubiesówka landslide (29120). Our graphs showed distinct landsliding in 1964, with the records of tree trunks arranged linearly along the slope of the Kubiesówka (29120) and Chupki (29121) landslides. The dendrochronological analysis indicated the movement of the entire Nad Zielona (29115) and Nad Zieloną (29116) landslides, as well as some movement in the Kubiesówka landslide (29132) along the Kubiesówka River in 1971-1972. 


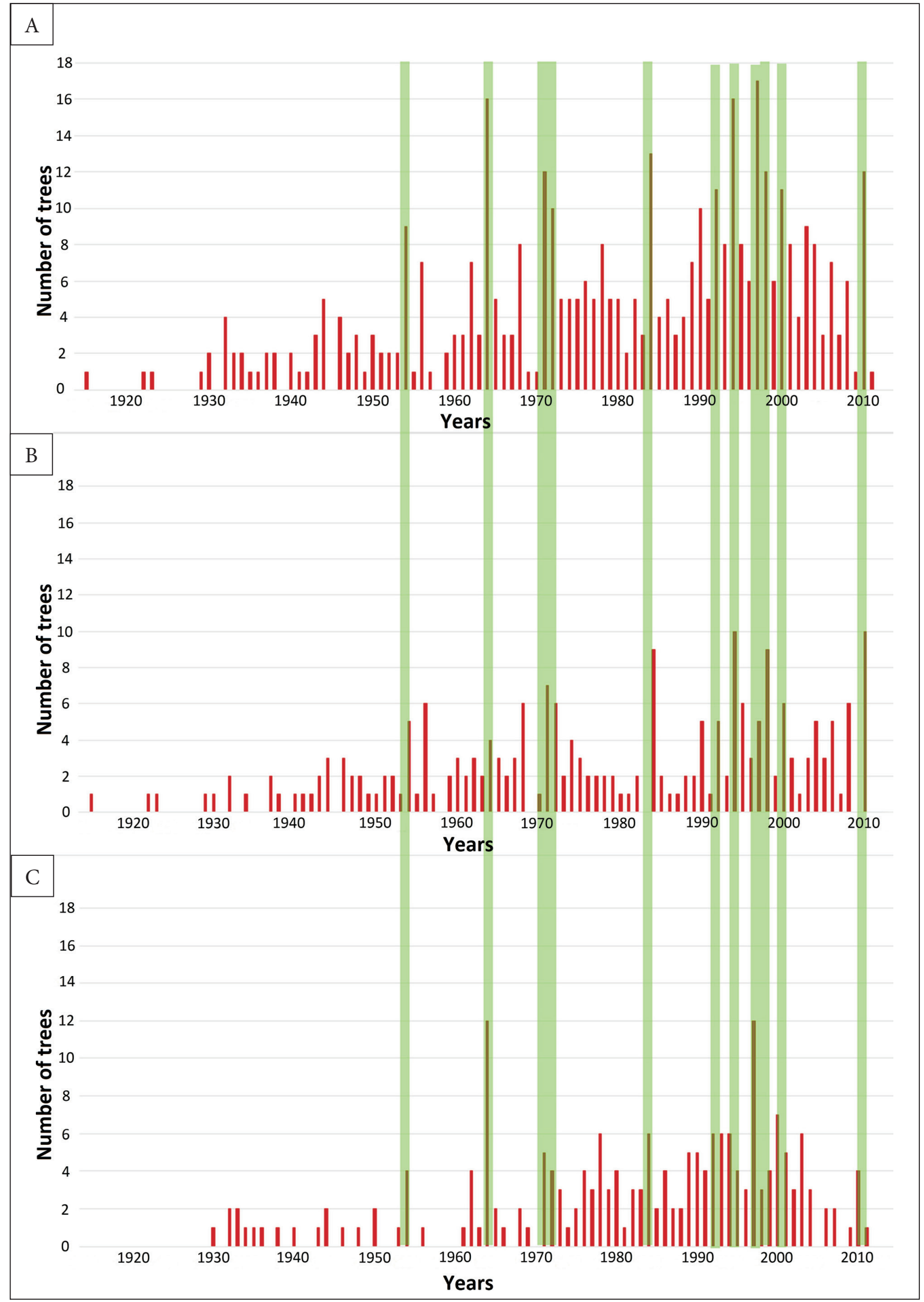

Fig. 4. The numbers of the trees recording landsliding: A) on the whole study area; B) on landslide areas: 29115 Nad Zielona and 29116 Nad Zielona; C) on landslide areas: 29120 Kubiesówka, 29121 Chupki and 29123 Kubiesówka 


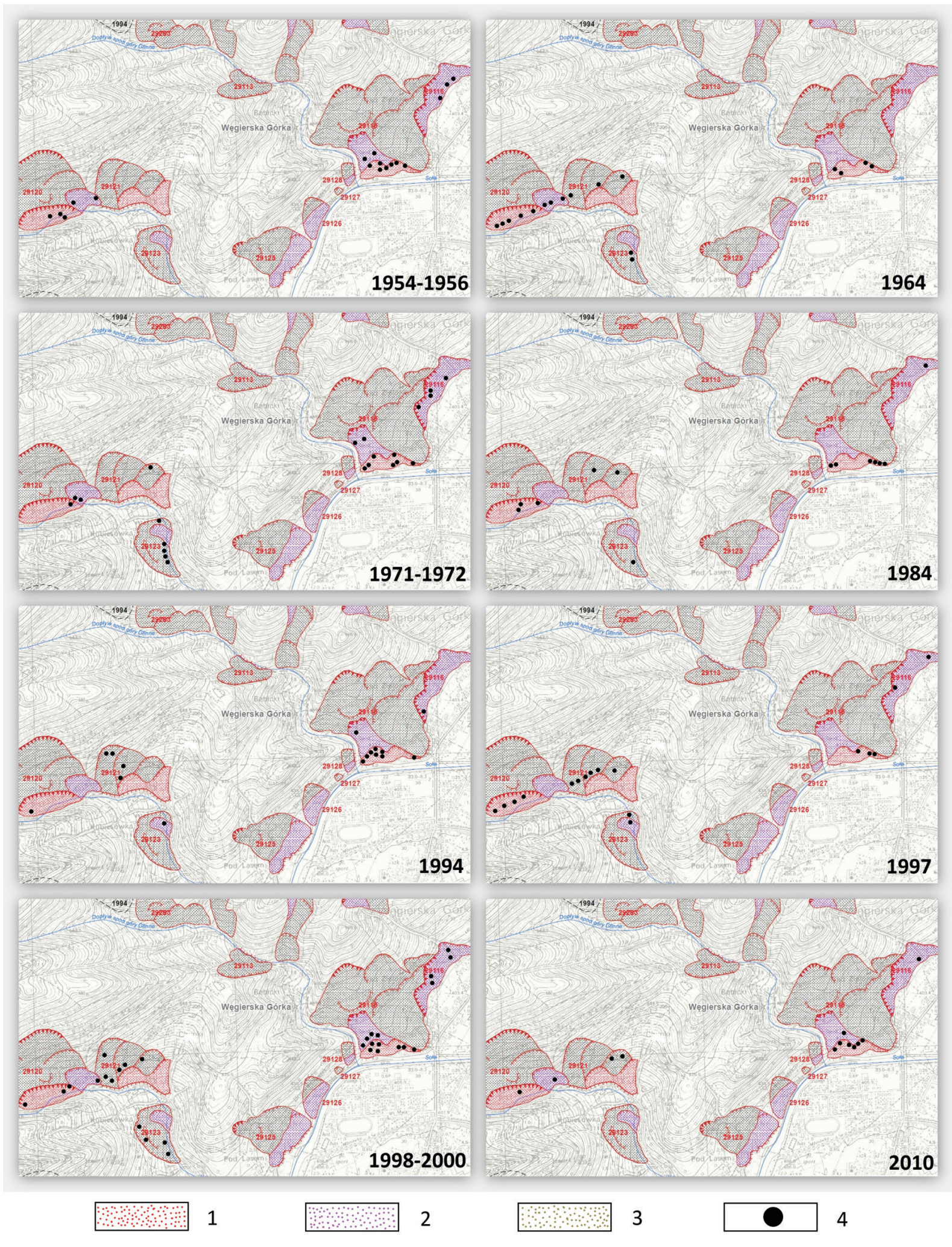

Fig. 5. The distribution of the trees recording landsliding in particular years: 1 - active landslide, 2 - periodically active landslide, 3 - non-active landslide, 4 - sampled trees

In 1984, a large concentration of trees indicated landsliding in the eastern section of the head of the continuously active Nad Zieloną landslide. In 1994, the western section of the same landslide became active. In 1997, the landsliding was stopped below the newly designed S-69 expressway, although 
landslide activity started once again along the slope at the Kubiesówka and Chupki landslides. Between 1998-2000, almost the entire studied landslide area was active. We recorded the activity of the Nad Zieloną landslide also in the first decade of the $21^{\text {st }}$ century, especially in 2010 .

\section{DISCUSSION}

Our studies allowed us to determine the range of mass movements in time and reconstruct the history of landslide activity. We also tried to identify the factors triggering the occurrence of landsliding in the study area.

The first aspect providing favourable conditions for the occurrence of landslides is geological structure. The Fore-Magura Nappe formations occurring in the bedrock are formed by Eocene variegated shale and Cretaceous variegated marls. Those were the lithological complexes of the Carpathian Flysch, conducive to landsliding (Kucharska \& Kamiński 2009).

Terrain relief could also be another factor causing slope activation. Currently, the most important factor transforming the Beskid Śląski Mountains relief is fluvial erosion. The head of the studied Nad Zielona landslide descends to the riverbed of the Sola River, while the heads of Kubiesówka and Chupki landslides descend to the riverbed of the Kubiesówka creek. During floods, linear erosion is activated. That process causes undercutting of river banks and leads to landsliding. The trend for the occurrence of large landslides is identified on steep slopes and in the valley heads or stream water sources where large slope fragments subside and collapse entirely, forming numerous steps.

In the last twenty years, intense landslides have occurred in Western External Carpathians several times in 1997, 2000, 2001, 2006, and 2010 (Poprawa \& Rączkowski 2000, Mrozek et al. 2000). The majority of those geomorphological phenomena were caused by extremely high precipitation occurring in the summertime. The landslide on the Prusów Hill in the Beskid Żywiecki range, studied in 2012 with the application of the dendrogeomorphological method, indicated activities in 1947, 1950, 1962, 1968, 1977, 1993, 1997, 2004, 2007, 2008, and 2010 (Wistuba et al. 2012).
Similarly, strong landsliding activity was identified in the studied area in 1964, 1968, 1994, 1997, 2000, and 2010.

Our dendrochronological analysis of the spruces growing on landslides in the Beskid Żywiecki and Beskid Śląski ranges (Krąpiec \& Margielewski 2000) displayed strong reactions to landslide movements in 1958 and 1960. In the mentioned years, catastrophic floods were recorded in the Beskid Żywiecki Mountains (Ziętara 1968). Similar rises in the curves were observed after the floods of 1970-1972. In those years, some of the highest daily precipitation levels were recorded in the Carpathians (Cebulak 1998-1999, 1992 - Klimczok and Leskowiec). Also, after the downpours occurring in the Soła River catchment area in 1980, diagnostic indications were found in the dendrochronological curves, peaking in 1985 (Krąpiec \& Margielewski 2000). Similar episodes were also recorded on the studied area in 1971-1972 and 1984.

Based on the measurement data collected from the nearby Meteorological Station in Żywiec, we drafted a graph showing the dependence of the number of the trees displaying their reactions to substrate movement in the given year and the total annual rainfall rates in the relevant or previous years (Fig. 6).

Significantly higher than average annual rainfall in the study area was noted mainly in 19221926, 1960-1963, 1965-1968, 1970, 1972, 19741977, 1980-1982, 1996-2000, and 2009-2010. Some of the largest floods occurred in the Soła River basin in 1958 and 1960 (Ziętara 1968). The next large flood was recorded in 1970. One of the largest post-thaw floods occurred in 1979, followed by a series of summer smaller inundations in almost the whole country in 1980. In July 1997, the largest catastrophic flood (the Millennial Flood), affected the country, while the most recent considerable floods was recorded seven years ago, in May and June of 2010.

Some of the mentioned years directly matching the increased numbers of events with eccentric tree growth indicated landslide activation. The year 1964 was preceded by several years of distinctly increased annual rainfall. The years 1971 and 1972 should be associated with the rainstorms of 1970-1972, preceded additionally by high precipitation sum in 1965-1968. The humid 
period of 1980-1982 was preceded by a distinct year 1984, which was well visible on our graph. The years 1994, 1997, 1998, and 2000 matched the humid period of 1994-2001, with its peak in 1997 (the Millennial Flood). Similarly, many trees indicated landsliding in 2010. That was also the time of one of the largest floods in Poland, preceded by the humid year of 2009 .

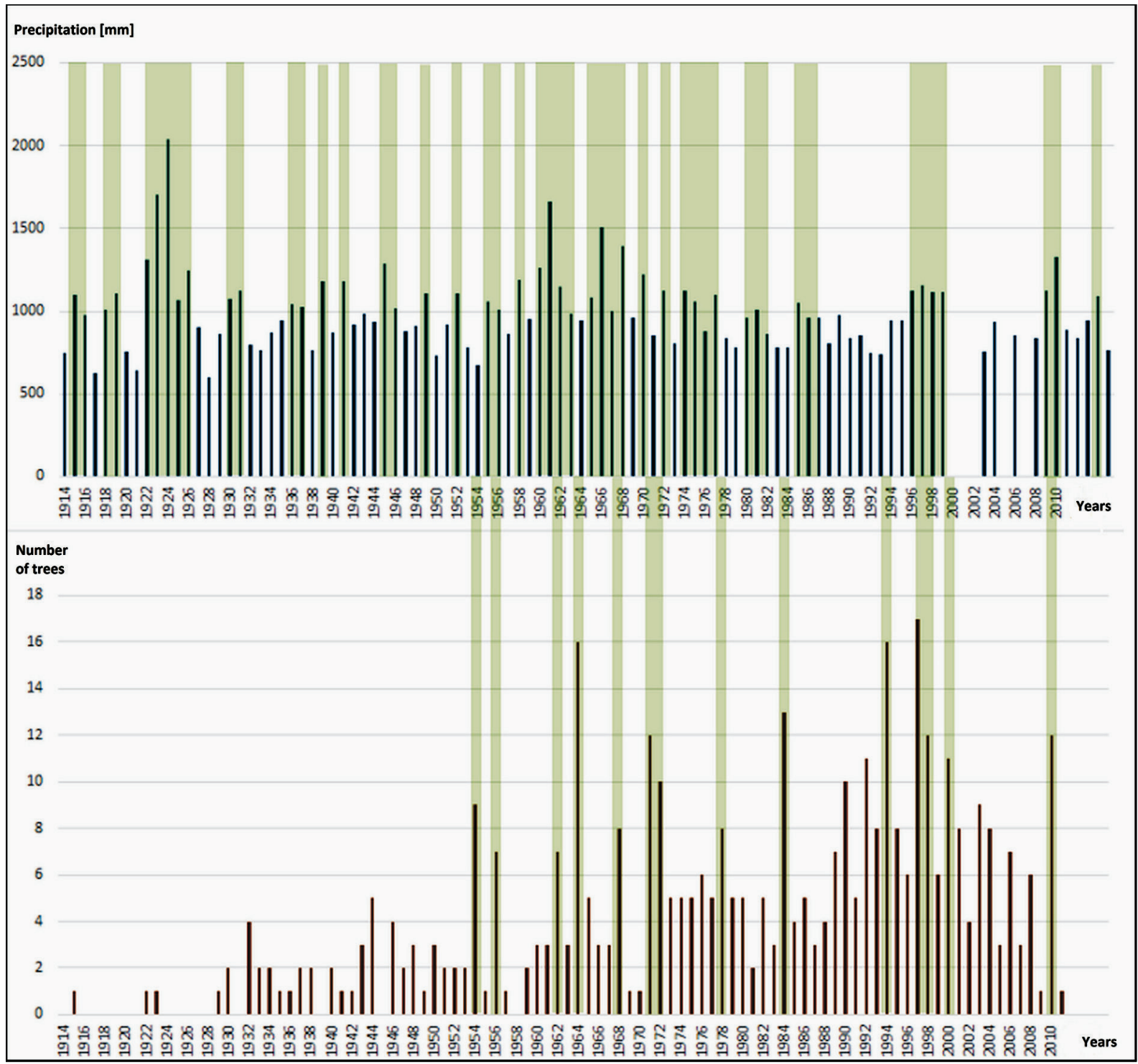

Fig. 6. Relationship between the numbers of the trees recording landsliding and the annual precipitation at the Meteorological Station in Żywiec

\section{CONCLUSIONS}

Typically, the bent or tilted tree trunks growing in our landslide study area allowed us to conclude that the studied landslide area has been unstable over the last few decades. The majority of the trees recorded landsliding in the years 1964, 1971, 1972, 1984, 1994 1997, 1998, and 2010. In many cases, those years were characterised by increased annual precipitation (in comparison to long-term averages). The largest landslide activity occurred in the 1990's. Our landslide activity maps allowed us to track the changes in the intensity of the landslide process in recent decades. Our dendrochronological analyses indicated that the studied landslides were still active and posed a threat to the newly designed S-69 expressway. 


\section{REFERENCES}

Alestalo J., 1971. Dendrochronological interpretation of geomorphic processes. Fennia, 105, 1-140.

Baillie M.G.L., 2008. Proposed re-dating of the European ice core chronology by seven years prior to the $7^{\text {th }}$ century AD. Geophysical Research Letters, 35, L15813, 1-5.

Bajgier M., 1989. Wpływ morfostruktury na rozwój głębokich osuwisk na stokach Skrzycznego w Beskidzie Śląskim. Folia Geographica. Series: Geographica-Physica, 21, 61-77.

Ballesteros J.A., Bodoque J.M., Díez-Herrero A., SanchezSilva M. \& Stoffel M., 2011. Calibration of floodplain roughness and estimation of flood discharge based on tree-ring evidence and hydraulic modelling. Journal of Hydrology, 403, 103-115.

Barański M., 2007. Beskid Śląski. Przewodnik. Oficyna Wydawnicza "Rewasz", Pruszków.

Braam R.R., Weiss E.E.J. \& Burrough P.A., 1987. Spatial and temporal analysis of mass movement using dendrochronology. Catena, 14, 573-584.

Burtan J., 1973. Objaśnienia do Szczegółowej mapy geologicznej Polski 1: 50 000. 1028, Arkusz Wisła. Wydawnictwa Geologiczne, Warszawa.

Butler D.R., 1979. Dendrogeomorphological analysis of flooding and mass movement, Ram Plateau, Mackenzie Mountains, Northwest Territories. The Canadian Geographer, 23, 62-65.

Cebulak E., 1992. Maksymalne opady dobowe w dorzeczu górnej Wisły. [in:] Hess M.T., Problemy klimatologii gór $i$ wyżyn, Zeszyty Naukowe Uniwersytetu Jagiellońskiego. Prace Geograficzne, 90, Uniwersytet Jagielloński, Kraków, 79-96.

Cebulak E., 1998-1999. Charakterystyka wysokich opadów wywołujących wezbrania rzek karpackich. Folia Geographica, Series Geographica-Physica, 29-30, 43-65.

Corominas J. \& Moya J., 1999. Reconstructing recent landslide activity in relation to rainfall in the Llobregat River basin, Eastern Pyrenees, Spain. Geomorphology, 30, 79-93.

Degraff J.V. \& Agard S.S., 1984. Defining geologic hazards for natural resources management using tree-ring analysis. Environmental Geology, 6, 3, 147-155.

Dikau R., Brunsden D., Schrott L., Ibsen M.L. (Eds.), 1996. Landslide recognition: Identification, Movement and Causes. J. Willey \& Sons, New York.

Gutiérrez F., Soldati M., Audemard F. \& Bălteanu D., 2010. Recent advances in landslide investigation: issues and perspectives. Geomorphology, 124, 95-101.

Jacoby G.C., Sheppard P.R. \& Sieh K.E., 1988. Irregular recurrence of large earthquakes along the San Andreas fault: evidence from trees. Science, 241, 196-199.

Krąpiec M. \& Margielewski W., 1991. Zastosowanie analizy dendrogeomorfologicznej $\mathrm{w}$ datowaniu powierzchniowych ruchów masowych. Geologia: kwartalnik Akademii Górniczo-Hutniczej im. Stanisława Staszica w Krakowie, 17, 1-2, 67-81.

Krąpiec M. \& Margielewski W., 2000. Analiza dendrogeomorfologiczna ruchów masowych na obszarze polskich Karpat fliszowych. Geologia: kwartalnik Akademii Górniczo-Hutniczej im. Stanisława Staszica w Krakowie, 26, 2, 141-171.
Kucharska M. \& Kamiński M., 2009. Objaśnienia do Mapy osuwisk i terenów zagrożonych ruchami masowymi w skali 1:10 000, gm. Wegierska Górka, pow. żywiecki, woj. ślaskie. [on-line:] http://geoportal.pgi.gov.pl/sopogview/objpdf?f=246 [access: 15.05.2017].

Lageard J.G.A. \& Drew I.B., 2008. Hydrogeomorphic control on tree growth responses in the Elton area of the Cheshire Saltfield, UK. Geomorphology, 95, 158-171.

Läänelaid A. \& Eckstein D., 2010. Tree Growth in an Area Subsided due to Mining Activities in Northeast Estonia. Baltic Forestry, 16, 2, 180-186.

Läänelaid A., Eckstein D. \& Seo J.W., 2009. Impact of underground mining of oil shale in northeastern Estonia on Scots pine and Norway spruce growing thereon. Oil Shale, 26, 73-84.

Mrozek T., Rączkowski W. \& Limanówka D., 2000. Recent landslides and triggering climatic conditions in Laskowa and Pleśna Regions, Polish Carpathians. Studia Geomorphologica Carpatho-Balcanica, 34, 89-112.

Nemčok A. 1982. Zosuvy v Slovenských Karpatoch. Veda, Bratislava.

Poprawa D. \& Rączkowski W., 2000. Zarys budowy geologicznej. Karpaty zewnętrzne (fliszowe). [in:] Alexandrowicz Z. \& Poprawa D. (Eds.), Ochrona georóżnorodności $w$ polskich Karpatach, $z$ mapa chronionych i proponowanych do ochrony obszarów i obiektów przyrody nieożywionej 1: 400 000, PIG, Warszawa, 21-26.

Shroder J.F., 1978. Dendrogeomorphological analysis of mass movement on Table Cliffs Plateau, Utah. Quaternary Research, 9, 168-185.

Shroder J.F., 1980. Dendrogeomorphology: Review and new techniques of tree-ring dating. Progress in Physical Geography, 4, 161-188.

Šilhán K. \& Stoffel M., 2015. Impacts of age-dependent tree sensitivity and dating approaches on dendrogeomorphic time series of landslides. Geomorphology, 236, 34-43.

Starkel L., 1960. Rozwój rzeźby Karpat fliszowych w holocenie. Prace Geograficzne - Polska Akademia Nauk. Instytut Geografii, 22, Wydawnictwa Geologiczne, Warszawa.

Stefanini M.C., 2004. Spatio-temporal analysis of a complex landslide in the Northern Apennines (Italy) by means of dendrochronology. Geomorphology, 63, 191-202.

Stoffel M. \& Bollschweiler M., 2008. Tree-ring analysis in natural hazards research - an overview. Natural Hazards and Earth System Science, 8, 2, 187-202.

Stoffel M., Butler D. \& Corona C., 2013. Mass movements and tree rings: A guide to dendrogeomorphic field sampling and dating. Geomorphology, 200, 106-120.

Stoffel M. \& Wilford D.J., 2012. Hydrogeomorphic processes and vegetation: disturbance, process histories, dependencies and interactions. Earth Surface Processes and Landforms, 37, 9-22.

Szychowska-Krąpiec E., 2010. Long-term chronologie of pine (Pinus sylvestris L.) and fir (Abies alba Mill.) from the Małopolska region and their palaeoclimatic interpretation. Folia Quaternaria, 79, 1-120.

Wistuba M., Malik I., Gärtner H., Kojs P. \& Krąpiec M., 2012. Zastosowanie dekoncentryczności przyrostów rocznych świerka pospolitego (Picea abies Karst.) w analizie dynamiki osuwiska - przykład z masywu Hrubégo Jeseníka (Sudety Wschodnie). Studia i Materialy Centrum Edukacji Przyrodniczo-Leśnej, 14, 1, 185-194. 
Wistuba M., Malik I., Gärtner H., Kojs P. \& Owczarek P. 2013. Application of eccentric growth of trees as a tool for landslide analyses: The example of Picea abies Karst. in the Carpathian and Sudeten Mountains (Central Europe). Catena, 111, 41-55.

Wójcik A. \& Wojciechowski T., 2016. Osuwiska jako jeden z ważniejszych elementów zagrożeń geologicznych w Polsce. Przegląd Geologiczny, 64, 701-709.
Zabuski L., Thiel K. \& Bober L., 1999. Osuwiska we fliszu Karpat polskich: geologia, modelowanie, obliczenia stateczności. Instytut Budownictwa Wodnego PAN, Gdańsk.

Zielski A. \& Krąpiec M., 2015. Dendrochronologia. Wydawnictwo Naukowe PWN, Warszawa.

Ziętara T., 1968. Rola gwałtownych ulew i powodzi w modelowaniu rzeźby Beskidów. Prace Geograficzne - Polska Akademia Nauk, 60, Wyd. Geologiczne, Warszawa. 